\title{
Recurrent pyogenic granuloma associated with port-wine stain - a case report
}

\author{
Granuloma Piogênico recorrente associado à Mancha Vinho do Porto - um relato de caso
}

Raiana Costa Silva ${ }^{1, a, b}$, Bruna Milhomens de Sousa ${ }^{2, a, c, d}$, Luisa Moura Fialho ${ }^{1, a, d, e}$, Clovis Lamartine de Moraes Melo Neto ${ }^{2, \mathrm{ad}, \mathrm{f}}$, Rodrigo Lorenzi Poluha ${ }^{2, \mathrm{add}, \mathrm{f}}$, Melaine de Almeida Lawall ${ }^{3, \mathrm{ag}, \mathrm{h,i}}$, Erika Martins Pereira $1, \mathbf{a , c}, \mathbf{i j , j . k}$.

\section{RESUMO}

O granuloma piogênico (GP) é um processo proliferativo não neoplásico. Este termo entretanto, é equivocado, uma vez que não está relacionado a qualquer infecção, não contém pus e não é um verdadeiro granuloma. A ocorrência do GP recorrente associado a lesões vasculares na pele, tais como manchas de vinho do porto, tem sido descrita na literatura. Paciente do gênero masculino com 23 anos de idade foi atendido na Universidade Federal do Maranhão apresentando uma lesão com características de granuloma piogênico na vestibular do primeiro molar, associada à mancha vinho do porto. O diagnóstico foi confirmado através de biopsia excisional e análise histopatológica. Devido à recorrência da lesão após a abordagem cirúrgica, injeções intralesionais de corticoides foram realizadas três vezes. Após dois anos de acompanhamento, não houve recorrência. Pode-se concluir que, apesar da alta prevalência de recorrência do granuloma piogênico, injeções intralesionais com corticoides podem ser uma alternativa ao tratamento cirúrgico convencional.

PALAVRAS CHAVE: Granuloma Piogênico, Mancha Vinho do Porto, Corticoid

\section{SUMMARY}

Pyogenic granuloma (PG) is a non-neoplastic proliferative lesion. This term, however, is a misconception, since it is not related to any infection, does not contain pus and it is not a true granuloma. The occurrence of recurrent PG associated with vascular lesions on the skin, such as port-wine stains, has been described in the literature. A

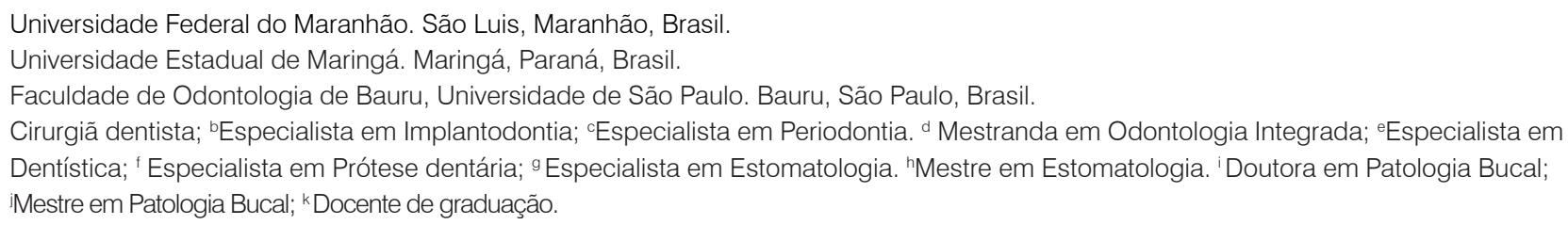


23 years old male patient was attended in the Federal University of Maranhão presenting a lesion with pyogenic granuloma characteristics in the buccal side of the first molar associated with port-wine stain. The diagnosis was confirmed per an excisional biopsy, along with histopathologic analysis. Due to the recurrence of the lesion after the surgical approach, intralesional corticosteroid injections was performed three times. After two-years no signs of recurrence could be observed. In conclusion, despite of the high prevalence of Pyogenic Granuloma recurrence, intralesional corticosteroid injections may be an alternative option to conventional surgical treatment.

KEYWORDS: Pyogenic granuloma, port-wine stain, corticosteroid.

\section{INTRODUCTION}

Pyogenic granuloma (PG) is a non-neoplastic proliferative process (1). Demographic data reports no gender predilection while some authors believe that it is more common in women. This lesion may be related to pregnancy, due to hormonal alterations, and oral contraceptive use (1-4). Clinically, these lesions present as a single shining nodule, sessile or pediculated, varying color from pink to intense red and presenting smooth or lobed surface. PG is consistent to palpation and usually shows an ulcerated surface due to trauma. It also shows a tendency to bleeding spontaneously or after gentle irritation (2,5-7). The PG etiopathogeny is not well-described (2,8-10). In general, it is believed that persistent trauma and irritation leads to an ulceration that does not get better. Therefore, there is a granulation tissue abundant formation, resulting in the lesion formation (2).

Pyogenic granuloma presents differential diagnostic with some lesions such as Peripheral Granuloma of Giant Cells, Metastatic Carcinoma, Kaposi Sarcoma, Melanoma, and Peripheral Fibroma $(1,2,11)$. Definitive diagnosis is confirmed by biopsy and histopathological examination associated with clinical data such as gender, pregnancy, trauma history, medication use, symptomatology, lesion progression and systemic diseases $(8,6,12,13)$. The correct diagnosis is fundamental for an effective treatment $(1,2,14)$.

PG can be associated with some syndromes, such as Sturge-Weber Syndrome (SSW) (6,15). In this syndrome, the patient exhibit vascular proliferations involving brain and face tissues. The facial alteration is known as Port-Wine Stain (PWS) and involves innervated skin by one or more branches of the trigeminal nerve, most commonly, the distribution of the first division of this nerve $(4,16)$. Some incomplete forms of SSW are frequent in which patients have only PWS with no brain involvement (4).

Therefore, the aim of this paper was to show a case report of PG associated with Port-Wine Stain.

\section{Case report}

A 23-year-old male patient was referred to the Federal University of Maranhão with a fast growth lesion in the buccal side of the first lower left molar, involving the interproximal area of the first and second molar. The lesion was lobular, erythematous, with bleeding on touch (figure 1). The patient related to have surgically treated this lesion twice but it has recurred in less than 60 days after the treatment. In addition, the patient had a PWS in the lower portion of the left face (figure 2). The diagnostic approach recommended

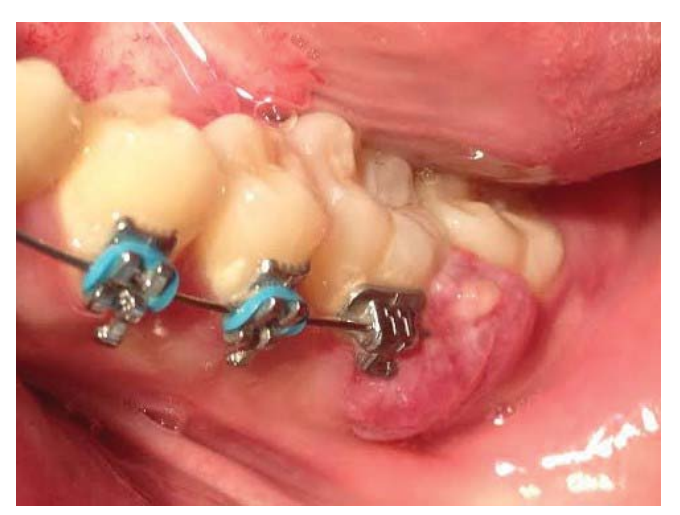

Figure 1. Pyogenic Granuloma in the buccal side of the first lower left molar

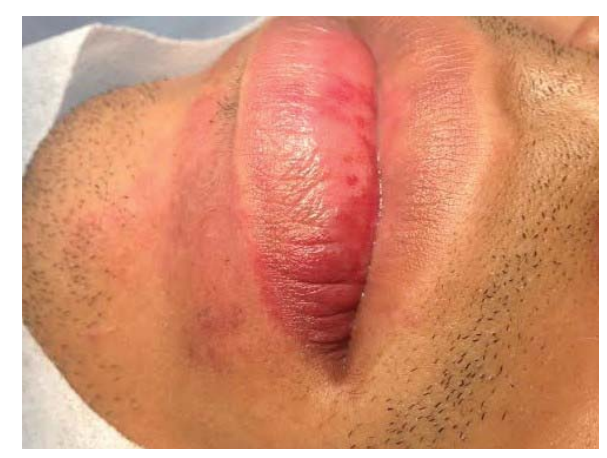

Figure 2. Port-Wine Stain in the lower portion of the left face 
was an excisional biopsy, along with histopathologic evaluation.

After a regional anesthesia, an excisional biopsy of the lesion was performed with a 15c blade (Solidor, São Paulo, Brazil), preserving the interdental papilla. In this case, the debridement to make sure that the entire lesion has been removed was not possible due to the great bleeding during the surgery. Therefore, it was decided to delay it for 30 days.

The specimen was prepared and treated histologi- cally. The histopathologic examination, using a light microscopy, showed a piece of soft tissue lined by parakeratinized stratified squamous epithelium exhibiting areas of spongiosis and acanthosis. In addition, ulceration areas recovered by a fibrinopurulent membrane were observed. In this areas, it has been found granulation tissue with fibroblasts interspersed by numerous blood vessels of different sizes and a diffuse infiltrate of mixed inflammatory cells such as neutrophils, lymphocytes and plasma cells (figure 3). These findings were consistent with a diagnosis of pyogenic granuloma.
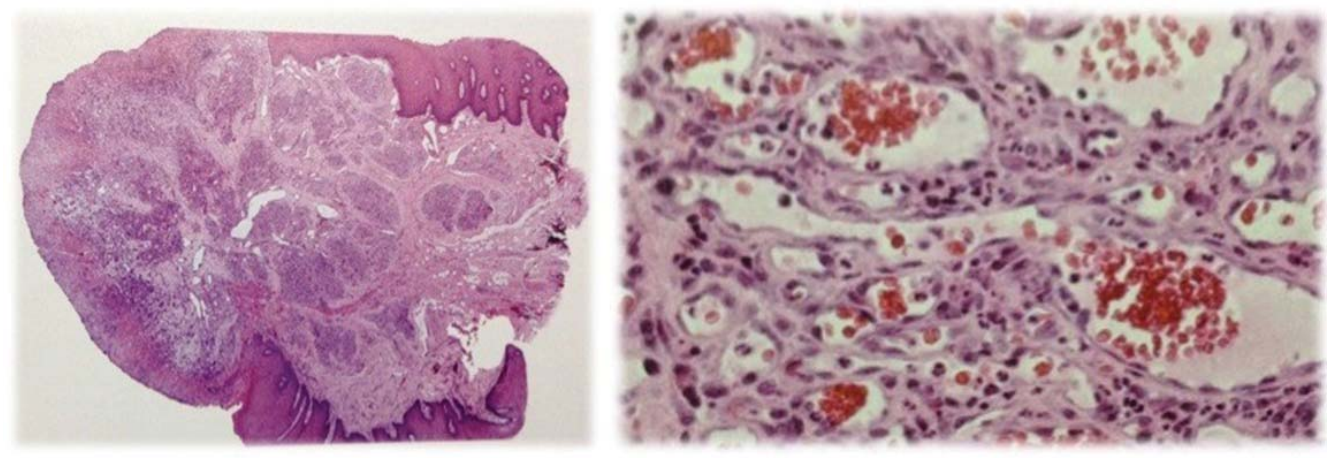

Figure 3. Histological analysis of the Pyogenic Granuloma

The patient was evaluated after one week. At this time, he showed a normal healing process. However, after one month, the lesion recurred this time in both, the buccal and the lingual side. Once again an excision was performed, but now the interdental papilla was removed and a debridement with a Gracey curette 5/6 (Trinity, São Paulo, Brazil) was done. Nevertheless, there was recurrence of PG 21 days after the second surgery (figure 4). At this time the lesion was smaller than before.

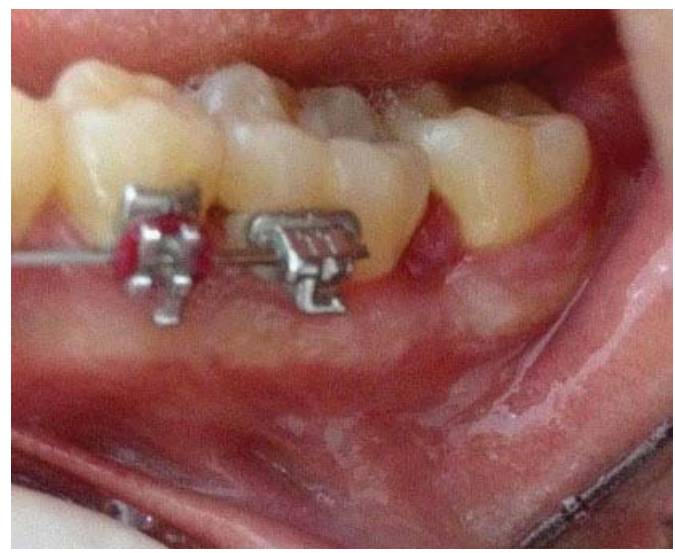

Figure 4. Pyogenic Granuloma recurrence 21 days after the second surgery
Due to failure of surgical management, an alternative approach with intralesional corticosteroid injections was performed. A solution was prepared by diluting 0.1 of betamethasone dipropionate $(5 \mathrm{mg} / \mathrm{ml})$ and betamethasone disodium phosphate $(2 \mathrm{mg} / \mathrm{ml})$ with 0.5 $\mathrm{ml}$ of local anesthetic that can be bupivacaine. A total $0.1 \mathrm{ml}$ of the mixture was injected intralesional every $3 \mathrm{~cm}$ from the lesion to avoid tissue necrosis ${ }^{16}$ (figure 5). This protocol has been performed 3 times. After the

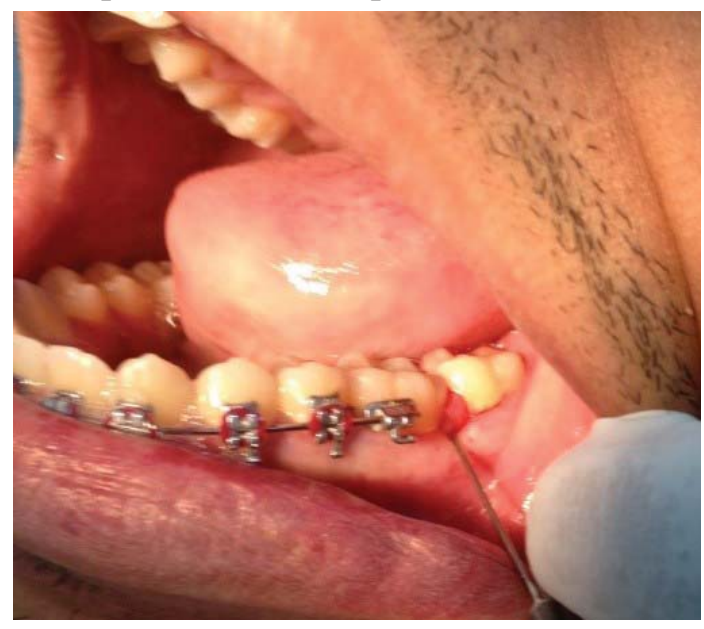

Figure 5. Intralesional corticosteroid injection 
treatment, the patient was referred to two-year follow up and showed no signs of recurrences (figure 6).

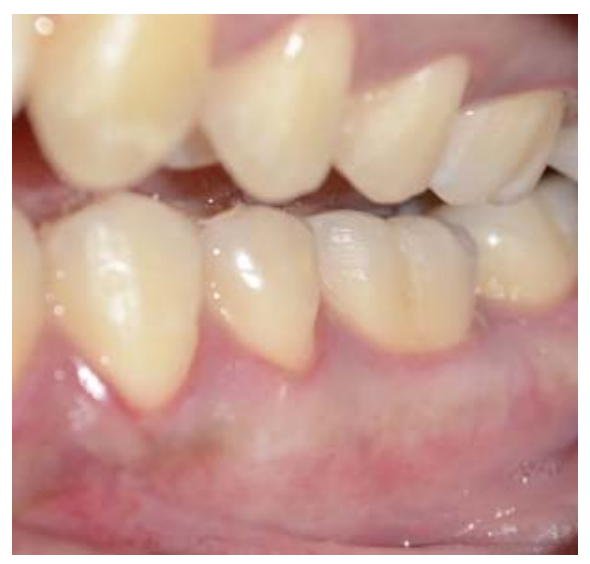

Figure 6. Absence of recurrence after a 2-year follow-up period

\section{DISCUSSION}

This patient was a 23-years-old male. Usually women are more susceptible to PG, especially the pregnant women, due to hormonal levels, and women who takes oral contraceptives $(1-4)$. Therefore, gender differ from others authors. In contrast, in this case, the age is in agreement with other data which affirm that this lesion is more common during the second and third decades of life (2). Both, clinical and histological analysis revealed all PG's characteristics described in the literature $(2,5,6,7)$. Histologically, PG has granulation tissue with endothelial proliferation in stroma of loose connective tissue and in some cases inflammatory infiltrate, especially in ulcerated areas. Numerous vascular spaces and many solid aggregate endothelial cells can be observed, sometimes organized in clusters lobulares (8). The lesion was involving the interproximal area of the first and second molar of the lower jaw. This is in disagreement with the literature that affirms that PG is common in the maxillary anterior $(1,7,12)$ and palate $(1,9,13)$.

PG may be associated to vascular alterations such as PWS $(5,12,17)$. Although this relationship is rarely described in the literature, PG may be an underreported complication of PWS (18). This association is caused by the arteriovenosa anastomosis in the vascular lesion, which leads to the PG development (4).

Local trauma, including lasertherapy in the treatment of PWS, may trigger the onset of pyogenic granuloma(18). In some cases, PG may appear without a history of trauma (18). In this case it was assumed that the presence of subgingival calculus was the trigger of the lesion. The calculus was removed in the first session, following the literature $(1,2,8,9,10)$. Pulsed dye lasers is the treatment choice for PWS, however, some of the PWS can be resistant to treatment with and about $10 \%$ of patients do not respond to treatment (19).

There is some non surgical treatment options for PG (i.e cryotherapy and laser), however their results are still not well established5.

Ideally, the treatment should allow confirmation of the diagnosis through histological analysis, preventing the inappropriate treatment of other tumors. Therefore the gold-standard treatment for PG remains the excisional biopsy of the lesion $(3,5,6,8,14)$. In this case, excisional biopsy of the lesion did not resolve definitely this patient's problem and the lesion recurred. Therefore, it was decided to inject intralesional corticosteroid as described in the literature (20). The anti-inflammatory and vasoconstrictive actions of the corticosteroids, may prevent or suppress the release of angiogenic factors (20). This protocol was performed 3 times and showed great outcomes. Two years after the treatment, no signs of recurrence could be observed. In conclusion, intralesional corticosteroid injections may be an alternative option to conventional surgical treatment.

\section{Correspondência:}

Raiana Costa Silva

Correio eletrônico: bruna.milhomens.s@gmail.com

\section{REFERENCES}

1. Amirchaghmaghi M, Falaki F, Mohtasham N, Mozafari PM. Extragingival pyogenic granuloma: a case report. Cases Journal. 2008; 1 (37): 1-3.

2. Capelari MM, Faccio RR, Marzola C, Toledo-Filho JL. Granuloma Piogênico- apresentação de caso clínico-cirúrgico Pyogenic Granuloma-surgical clinical case presentation. Tese de Doutorado. São Paulo: Universidade de São Paulo; 2009.

3. Dojcinovic I, RichterM, Lombardi T. Occurrence of a pyogenic granuloma in relation to a dental implant. J Oral Maxillofac Surg. 2010;68(8):1874-6. doi: 10.1016/j.joms.2009.06.015 
4. Silva AD, Silva CAB, Moraes PC, Thomaz LA, Furuse C, Araújo VC. Recurrent oral pyogenic granuloma in Port-Wine Stain. J Oral Maxillofac Surg. 2010;68(8):1874-6. doi: 10.1016/j.joms.2009.06.015

5. Avelar RL, Antunes AA, De Carvalho RWF, Santos TS, De Oliveira Neto PJ, Andrade ES de S. Granuloma Piogênico oral: um estudo epidemiológico de 191 casos. RGO. 2008; 56 (2): 131-135.

6. Wollina U, Langner D, França K, Gianfaldoni S, Lotti T, Tchernev G. Pyogenic Granuloma - A Common Benign Vascular Tumor with Variable. Open Access Maced J Med Sci. 2017; 5(4):423-426.

7. Kadeh H, Saravani S, Tajik M. Reactive hyperplastic lesions of the oral cavity. Iran J Otorhinolaryngol. 2015 Mar;27(79):137-44.

8. Rosa CG, Lay AC, La Torre AC. Oral pyogenic granuloma diagnosis and treatment: a serie of cases. Rev Odontol Mexicana. 2017; 21 (4): 244-252.

9. Chandrashekar B. Minimally invasive approach to eliminate pyogenic granuloma: A Case Report. Case Rep Dent. 2012;2012:909780. doi: 10.1155/2012/909780

10. Shivaswamy S, Siddigui N, Jain AS, Koshy A,Tambwekar S, Shankar A. A rare case of generalized pyogenic granuloma: A case report. Quintessence Int. 2011;42(6):493-9.

11. Krishnapillai R, Punnoose K, Angadi PV, Koneru A. Oral pyogenic granuloma-a review of 215 cases in a South Indian Teaching Hospital, Karnataka, over a period of 20 years. Oral Maxillofac Surg. 2012; 16: 305-309.

12. Mendonça JCG, Jardim ECG, Manrique GR, Lopes HB, Freitas GP. Granuloma Piogênico: relato de caso clínico-cirúrgico. Rev Bras Ciên Saúde. 2011; 9(29): 92-94.

13. Sapna P, Rakhi I, Vaishali K, Zameera N. An unusual presentation of pyogenic granuloma. Indian Journal of Dentistry. 2012; 3(3): 178-181.

14. Costa FWG, Lima ATT, Cavalcante RB, Pereira KMA. Exuberant pyogenic granuloma in extragingival site. Braz J Otorhinolaryngol. 2012; 78(4): 134.

15. Brightman LA, Geronemus RG, Reddy KK. Laser treatment of port-wine stains. Clin Cosmet Investig Dermatol. 2015; 8: 27-33.

16. Marinho AS, Cherubini K. Sturge-Weber Syndrome. Rev Odontol Univ Cidade SP. 2006;18(2): 167-73.

17. Dghoughi S, ElwadyW. Pyogenic granuloma (botryomycoma) of the tongue. Indian J. Dentistry. 2012;1: 1-4.

18. Gomes SR, Shakir QJ, Thaker PV, Tavadia JK. Pyogenic granulome of the gingiva: A misnomer? - A case report and review of literature. J Indian Soc Periodontol. 2013; 17: 514-9.

19. De Oliveira VA, Do Carmo AF, et al. Pyogenic granuloma in a patient with port-wine stain. Oral Surgery, Oral Medicine, Oral Pathology and Oral Radiology. 2017; 124 (2): 108-9. DOI: https://doi.org/10.1016/j. oooo.2017.05.250

20. Glick M, Glick PH, Parisi E. Recurrent intraoral pyogenic granuloma with satellitosis treated with corticosteroids. Oral Diseases. 2006; 12: 70-72.

Recibido: 19-05-2018

Aceptado: 15-12-2018 